An International Multidisciplinary Journal, Ethiopia Vol. 7 (3), Serial No. 30, July, 2013:324-339

ISSN 1994-9057 (Print)

ISSN 2070--0083 (Online)

DOI: http://dx.doi.org/10.4314/afrrev.v7i3.23

\title{
Democracy and Violent Conflicts in Nigeria: Implications for National Development
}

Joshua, Segun - Department of Political Science and International Relations, College of Development Studies, Covenant University, Ota, Ogun State, Nigeria

E-mail: joshuasegun2003@yahoo.com

\begin{abstract}
There seem to be a debate on the validity of democratic peace theory. While some scholars argued that democracy engenders peace, others argued exactly the opposite. In the Nigerian context, democracy appears to have been characterised by violence. With heavy reliance on secondary data backed by analytical approach, the paper examines democracy and violent conflicts in Nigeria and its implications for development with a particular focus on the Nigeria's Fourth Republic. The paper found that; the nature of competition for political power, multi-ethnic nature of the polity as well as corruption, unemployment and poverty are some of the factors which make democracy in Nigeria's Fourth Republic violent-ridden. The paper therefore, recommends among others, the need to cut down on the remuneration/allowances of political offices holders and emphasizes the reorientation of the political elite towards shunning divisive politics.
\end{abstract}

Key words: Democracy, Violent Conflict, Political Elite, Poverty, Nigeria 


\section{Introduction}

There seems to be a growing body of literature on the relationship between democracy and violent conflict. It is argued democracy is a panacea to violent conflict; in fact, it is one of the measures the United Nations (UN) often advocate in their intervention efforts in war torn countries (Paris, 2004). However, others argued that democracy rather than been a solution to conflict, is a major driver of conflict (Keane 2010).

Election, an integral feature of democracy, has equally generated much controversy. For example, Rapoport and Weingberg (2001) cited in Hoglund, 2006) contended that competitive election facilitates peaceful transfer of power and makes it possible to assign accountability to those who govern, to others, democracy come at a price because violence attend most elections. Thus, many people lose their lives in connection to competitive elections (Hoglund, 2006).

Nigeria's fourth republic appears to be very chaotic, incessant violent conflict ranges from religious, identity to communal. Elaigwu (2005a) identified 17 major violent conflicts in Nigeria from May 1985 to May 1st 1999. However, from May 31, 1999 to June 2005 he identified at least 121 cases of conflicts in Nigeria. He attributed sudden increase in violent conflict in the country to: a strong central government; popular agitation for decentralised structure; dissatisfaction with the distribution of available resources; communal conflicts and demands by some sub-national groups for greater selfdetermination (Eliagwu, 2005b). He continued that the years of military rule suppressed these issues from exploding into uncontrollable conflagration. $\mathrm{He}$ likened the Nigerian polity as a bottle of wine, properly corked and airtight. With the dawn of democracy and the opening of the bottle, the wine explosively popped up (Eliagwu, 2005b). It appears the dawn of democracy provided the atmosphere to ventilate bottled-up frustrations, grievances and fears generously and often times recklessly (Adebanwi, 2004).

Though there are several works on conflicts in Nigeria, few appear to link violent conflict in Nigeria to democracy with particular focus on the fourth republic. For example, Haliru (2012), focused on ethnicity, Onapajo (2012), focused on religion and political violence, Saheed (2012) emphasised economic dimension of social conflicts in Nigeria. 
It is against this backdrop that this paper examines democracy and violent conflict in Nigeria's fourth republic and its attendant implications for national development.

This paper is divided into the following segments for analytical purposes: following the introduction is section two that focuses on conceptual discourse and theoretical explanations; section three examines the linkage between democracy and violence in Nigeria and implications for national development; section four is conclusion and recommendations.

\section{Conceptual discourse on democracy}

To Sodaro (2001), the essence of democracy is that people have the right to determine who governs them, hold them accountable for their actions and also impose legal limits on the government's authority by guaranteeing certain rights and freedoms to their citizens.

The concept connotes acceptance of the people's will as supreme in governance of public affairs (Odulami, 2008). Democracy also means governments established by and with the consent of the people, almost always by the constitution; leaders are chosen by the people in free and fair elections; the government and its leaders obey the will of the majority of those who elected them to make laws (Pius, 1986). Democracy also means the sovereignty of the wishes and aspirations of the electorate in decision making (Adeyemo, 2009).

The views above suggest that democratic governance must reflect the wishes of the people and that people have the right to vote and be voted for via elections. Saliu and Lipede (2008) however observed that this brand of democracy, appropriately termed liberal democracy cannot be said to be representative enough as it emphasizes material conditions before citizens can adequately participate in the democratic exchange. The emphasis on minimum level of education and property acquisition before qualification for political office puts the elite in a vantage position to dominate the vast majority.

This lends credence to the statement credited to (Fukuyama 1992:43) that "... formal democracy alone does not always guarantee equal participation and rights". Saliu and Lipede (2008) noted that it is unfortunate that this brand of democracy that put the elite in a vantage position at the expense of the masses is in vogue, especially in transition countries and Africa in particular. Thus, the emphasis on liberal democracy paves the way for masses to be 
manipulated by the elite and this finds expression in mass violence by the poor in Nigeria.

\section{On Conflict}

The term conflict is taken from the Latin word 'conflictus' meaning "strike together". Conflict means clash, contention, confrontation, a battle or struggle or quarrel (Nwolise, 1997). Coser (1956 cited in Otite 2001) defines conflict as a struggle over values and claims of scarce status, power and resources, in which the aims of the opponents are to neutralise, injure or eliminate their rivals. It has also been noted that conflict arises as a consequence of the striving of man, the social being who in the course of promoting some of his objectives, either intentionally or unintentionally upsets and direct to negative uses, instead of strengthening along beneficial line, some of the arrangement that ought to be for the benefit of man (Nwangegbo, 2005). Conflict becomes violence when it is accompanied with threat and actual destruction of life and property. Keane, (2010) sees the relationship between democracy and violent conflict as exemplified in democratic process. The relationship between democracy and violent conflict is captured under theoretical discourse below.

\section{On Development}

Development has political, economy and social dimensions. Todaro (1980 cited in Joshua, Oni and Agbude, 2012:164) for instance; view development as: "a multi-dimensional process involving changes in structures, attitudes and institutions as well as the acceleration of economic growth, the reduction of inequality and the eradication of absolute poverty". It also include perception of individuals or groups of self-worth and esteem as a respected member of the society; and freedom in the sense that individuals and society at large have an expanded range of choice, not only material necessities for self reproduction but also in ability to have a say in, if not to determine, the method and process by which values are allocated in the society (Ogwu, 2002 cited in Joshua et. al, 2012:164).

Howard (2004) argues that development exists when the central problems of poverty, unemployment and inequality have reduced from high level. The objective of development is to extend the frontiers of human lives.

\section{Democracy and violent conflict: theoretical discourse}

Scholars do not agree with regards to the role of democracy in peace and violent conflict. Democratic theory as enunciated by Russet (2007:2) hinges 
on the fact that democracy leads to and engender peace as peace cannot be achieved in the absence of democracy.

Thus, it can be deduced from democratic peace theory that the more democratic countries are the more peace we have in the world. In fact, Moaz and Russet (1993), Remmer (1998) argued that the probability of two democratised countries engaging in militarised conflict is extremely low. Domestic norms and institutions prevalent in democratic politics have been advanced to be responsible for peaceful relationship among democratic countries. There seem to be no such constraints when they engage in dispute with non-democratic countries.

Rummel (undated) added that while about 36 million people have been killed in battle in all foreign and domestic wars in the last century, at least not less than 119 million have died through government genocide, massacres and other mass killings. And that about 115 million of these figures were killed by totalitarian governments (not less than 95 million of these 115 million mentioned above were in communist countries), and that there are no such records of democracy killing en masses their own citizens. He concluded that democratic freedom promotes non-violence.

However, democracy has dark side that sups with the devils of political violence; or it is claimed that democracy kills (Keane, 2010:2). Violence is inherent in every effort to establish and maintain democracy. The practice of democracy everywhere rests with foundational acts of violence (Keane, 2010). Reynal - Querol (2004) argued that partly democratic countries are more prone to civil war than full democracies, and full autocracies. Therefore, it appears that violence prevention or reduction does not rest solely on democratic status of a country alone. It has equally been observed that although democratic countries may not go into war with other democratic countries, however, they are often embroiled with internal conflict which is often precipitated by electoral contest.

Cervellati and Sunde (2011) contend that democratization process may trigger political violence because the scenario under which democratization takes place especially during democratic transitions provides convenient platforms for violent conflicts, especially among groups within a polity. Keane (2010) christened this democratization of violence. He added that the idea of democratic countries engaging undemocratic countries in war on some issues like that of America war in Afghanistan and in other countries 
only to introduce democratic governance after subjugating them is tantamount to democratization of violence.

There is a convergence in views by Hoglund, (2006) and Horowitz (1985) that competitive elections result in ethnicization of electorate. Instead of bringing their similar virtue to the table, political parties rather emphasize their differences to win votes (Weinberg 2001 cited in Hoglund, 2006). Thus, in plural societies, voters tend to vote according to their ethnic identity and thus the election results become almost identical to that of the ethnic census. This could cause trouble for post electoral politics in such a country and thus become a cause of ethnic conflict (Taleski 2011).

Rapoport and Weinberg (2001) stated that the situation immediately after elections is often very sensitive as the acceptance or otherwise of the outcome of elections by contenders can produce outbreaks of violence as it was the case in East Timor after the 1999 referendum of independence. From the above, it can be inferred that although the universal position is that democracy midwives peace, however, democracy alone cannot bring about peace as evidenced in some countries undergoing democratization such as Cote D'Ivoire, Democratic Republic of Congo, and old Sudan among others. This is because elections which are cardinal features of democratization often generate conflicts in partially democratic countries.

\section{Democracy and violent conflicts in Nigeria's fourth republic}

Although conflict in Nigeria predates the inception of civil rule in 1999, the frequency of conflicts in all the geo-political zones at one time or the other in the present democratic dispensation calls for concern. Osita (2007) heaps the blame of Nigeria's violent conflicts on corruption and the abrupt termination of the late General Abacha, one of the ruthless military dictators Nigeria has ever had. His demise triggered spontaneous culture of "revivalism and agitation among different social grouping" (Osita 2007: 21). This was because pent up aggression under the ruthlessness of Abacha's regime now found expression among the various ethnic groups. Added to this is the fact that long period of repressive military rule has led to the militarization and bastardization of the psyche of Nigerians (Agbaje, 2003), hence the frequent conflicts in form of religious and ethnic in the country. The discussion above contextualised conflicts in the Nigerian fourth republic within the long period of military rule. However, other areas that are germane in the discussion of democracy and violent conflicts in Nigeria's fourth republic are discussed below. 


\section{The Nature of politics}

The intense nature of competition for political power especially in the fourth republic has made violence to be associated with democracy in Nigeria. Nigerian politicians, over the years, have "become more desperate and daring in taking and retaining power and more intolerant of opposition, criticism and efforts at replacing them" (Alemika, 2011:1).

Obasanjo the first president in the fourth republic from 1999-2007 asserted that "we fight and sometimes shed blood to achieve and attain political power because for us in Nigeria, the political kingdom has for too long been the gateway to economic kingdom" (Obasanjo, 2002:50-51). Similarly, Omoweh and Okanya (2005:303) noted that "political competition for the control of the state and its political power is now a bloody warfare as the state holds the key to wealth".

The above scenario explains why election which is the means of political power acquisition in democratic governance has been violent ridden most especially in the fourth republic. That is why Abbass (2008) opined that election period in Nigeria is best described as warfare. According to Human Right Watch (2011), at least 100 people died in federal and state election in 2003; not less than 300 people were killed in violence linked to the 2007 elections and well over 800 people were victims of electoral violence in 2011 presidential elections alone in the North with more than 65,000 people displaced. (These figures did not include those that died in intra and interparty conflicts).

\section{Multi-ethnic nature of Nigeria and religious rivalries}

Salawu (2010) noted that Nigeria has over four hundred (400) ethnic groups, belonging to several religious sects, thus, Nigeria since independence has been grappling with the problem of ethnicity on one hand and religious conflicts on the other hand. Haliru (2012) contended that the ethnic and religious composition of Nigeria and its manipulation by the political elite poses a lot of threat to governance and security of Nigeria. The inability of the state to perform its constitutional duties of maintaining law and order, justice and providing social services for the people has culminated in the emergence of ethnic militias in several parts of the country such as the Oodua People's Congress (OPC), Bakassi boys, Egbesu boys and the emergence of Boko Haram in Northern Nigeria. Salawu (2010) opined that the emergence of ethnic militias and the deep divides between the various ethnic groups; 
makes religious intolerance more violent and bloody with more devastating consequences using the ethnic militias as the executors of the ethno-religious agenda. Salawu (2010) also notes that over $40 \%$ of ethno-religious based conflicts are credited to the fourth republic of Nigeria.

Harris and Reilly, (1998) cited in Haliru (2012) have also argued that conflict originating within state can largely be traced to potent identity base factors, translating to differences in race, religion, culture, language and so on with perceived imbalance in the distribution of economic, political and social resources. This is very relevant to the Nigerian situation. For instance, shortly after the annulment of the June 12, 1993 Presidential election, the perception of some groups in the federation over the disequilibrium in Nigeria's body politics became acute. The Ogonis felt neglected, the oil producing states felt cheated, the northern minorities felt left out, the West felt robbed, the core north felt they only held the titles but real power has been elsewhere, the East has always felt oppressed and marginalized. These feelings resulted in the formation of ethnic militias by some of the groups to redress their unhappy positions in the federation (Agbaje, 2003). Their activities have been a threat to peace and security in the country.

With reference to Nigeria, there seem to be a divisive interplay of politics, ethnicism and religions which has consequently given fillip to the rising micro nationalism and militancy of various ethnic and religious movements in a bid to correct perceived form of marginalization, oppression or domination. Hence, the escalation of ethno-religious conflicts that now looms large in the country.

Adagba, et al, (2012) have equally noted that the interplay of ethno-religious conflicts and politics in Nigeria boils down to perceived or real loss of power by an elite stratum, the quest for political power among those who won it before, those that lost it and those who want it back. And politicians are known for playing ethnic cards for their selfish political gains. That is, inciting their own ethnic group against their opponent's ethnic group. The violence that trailed the release of the 2011 presidential election in Nigeria, in the northern parts of the country, (the home of the major presidential candidate General Buhari (rtd) that lost out in the election) buttresses this fact.

Added to the insecurity baggage is the Boko Haram insurgency in the north that has left not less than 16,000 policemen, soldiers and civilians, including politicians dead (Ogbonaya et al, 2012). 


\section{Corruption, unemployment and poverty}

Adesoji, (2010) is of the opinion that public sector corruption leading to misuse of resources, unemployment and mass poverty; ignorance due to limited educational opportunities swelled the army of vulnerable people whose disillusionment and impoverishment made them easy prey in the hands of demagogues like the late Yusuf the first leader of Boko Haram that has been a security threat to Nigeria. It is important to state that the fourth republic is very pivotal in analyzing the relationship between poverty and violent conflicts in Nigeria. Studies have shown that there is an increase in the rate of poverty in the fourth republic. The poverty level in 1999 was put at $45 \%$ but increased to $76 \%$ in 2012 due to mismanagement of the country's resources by corrupt leaders (Egharevba and Chiazor, 2012). It was also observed that the money that was made from oil between 1999 and 2011 was more than all that was made from 1960-1999 (Save Nigeria Group, 2012), but squandered by Nigerian leaders through corruption, leaving the masses in poverty-stricken conditions (Egharevba and Chiazor, 2012). According to National Bureau of Statistics (2012), the Nigerians that live on less than \$ 1 per day are not less than two-thirds of the total Population. This implies that 112.5 million Nigerians out of the estimated 163 million are living in poverty.

Marke, (2007) cited in Ikiejiaku, (2012) postulated that the account of political corruption perpetrated by African leaders are catholic and these has taken toll on the provision of human needs, with implications on conflict. $\mathrm{He}$ said youths that are not engaged in meaningful work, and can no longer cope with the burden of poverty caused by leadership corruption bring attention to their plight by engaging in destructive behaviour. Ikejiaku (2012) also noted that violence in the Niger Delta has been spearheaded mainly by restive and often unemployed youths. In fact, violence seems to be more in areas that experience more poverty.

\section{Implications of violent conflict to Nigeria's national development}

Conflict has high direct and indirect cost. In fact, violent conflict seems to be the pathway to poverty and a major challenge to the development of most countries embroiled in conflicts in Africa. In Nigeria, various violent conflicts the country has experienced are taking a heavy toll on the country's development. Adeyemo, (2006 cited in Saheed, 2012) submits that the insecurity of lives and properties which tends to prevent foreign economic relations to jumpstart the economy is one of the major implications of 
persistent conflicts in the land. In the same vein, Saheed, (2012) noted that victims of ethno-religious conflicts while taking refuge in refugees camp are cut off from optimal engagement in economic activities. In that condition, they cannot make meaningful contributions to the development of the country. Ibeanu, (2009) observed that between 2003 and early 2005, over 30,000 people died in election related violence in the Niger Delta perpetrated by youths, with properties worth hundreds of millions destroyed. It has equally been noted that over 9000 people have lost their lives in fight between Ijaw gangs (Jawondo, 2011). It is also on record that since 1999, there have been over 90 violent ethno-religious conflicts in the country with over 100,000 lives lost in the process (Nwanolue and Iwuoha, 2012). The able-bodies wasted in senseless ethno-religious and other types of crises in the country can no longer contribute to the socio-political and economic development of Nigeria.

Similarly, properties lost to various conflicts and compensations paid by the various governments cannot be ploughed back to developmental objectives. In fact, a total of $\mathrm{N} 150$ billion oil revenue has been deferred and property worth billions of naira destroyed in communal clashes nationwide (Yahaya, 2005). The government of Delta State in 2003 spent N200 million to maintain soldiers stationed in Warri to maintain peace (Adebanwi, 2004). Indeed, conflicts have led to loss of assets both by victims and the diversion of public funds from developments to pay compensation to victims. For example it is estimated that assets worth N59, 672,000 were lost to the Jos crisis in 2001, while government compensation to victims was about N13, 938,000; assets lost to the Kaduna crisis of 2001 amounted to N50,625,000, with government compensation at N32,716,000. The Kano crisis of 2001 resulted in the loss of asset worth $\mathrm{N} 59,756,000$, while compensation totaling about N22,658,000; assets lost to Jos crisis of 2004 was estimated at about $\mathrm{N} 102,932,000$ while $\mathrm{N} 85,121,000$ was paid as compensation to victims (to mention just a few ) (Yahaya, 2005). Added to the above is the fact that continued insecurity in the country has not only discouraged transnational corporations to invest, but has equally caused the established ones to divest by way of folding up their businesses (Afegbua, 2010).

\section{Conclusion and recommendations}

In this paper, attempt has been made to establish a relationship between democracy and violent conflicts with a particular focus on the Nigerian 
fourth republic. Some factors have given impetus to violent conflicts in Nigeria were highlighted, the paper recommends that;

- benefits accruable to political offices be reduced to make them less attractive. This is because privileges associated with political offices engender violent competition for them.

- Political elite should be re-orientated towards emphasizing things that unite them rather than things that separate them.

- Political corruption that has made Nigeria a rich nation with poor people should be addressed seriously and capital punishment meted out to corrupt public officers to serve as deterrent to others.

- There is need for societal re-orientation towards holding public office holders accountable. Nigerian education should be tailored towards meeting the immediate needs of our society. Education system should go beyond paper qualification. There is need to align our education system towards the needs of the society.

- Politicians should take the issue of building and integrating the disparate groups in the country very seriously.

- Government should come up with an acceptable formula for sharing federally collected revenue as this has been a vexed issue among the various groups in the country.

- There is need to build the culture of peace among the citizenry as this will tone down the culture of violence people have already imbibed especially under military rule. 


\section{References}

Abbass (2008). "Electoral Violence in Nigeria as the Problem of Democratic Politics" A Paper Presented at the 7th Annual Conference of the Nigerian Political Science Association and Electoral Reform, Political Succession and Democratization in Africa, held at Benue State University, Makurdi from 16-19 November.

Adagba, O., Ugwu, S.C. \& Eme, O.I. (2012). “Activities of Boko Haram and Insecurity Question in Nigeria" Arabian Journal of Business and Management Review (OMAN) 1(9):77-99

Adebanwi, W. (2004). "Democracy and Violence: The Challenges of Communal Clashes" in Adigun, A, Diamond, L. and Onwude, E. (eds) Nigeria's Struggle For Democracy and Good Governance A Festschrist for Oyeleye Oyediran, Ibadan: University Press. Pp: 327348

Adesoji, A. (2010). "The Boko Haram Uprising and Islamic Revivalism in Nigeria, Africa Spectrum, 45 (2):95-108

Adeyemo. A. (2009). Paris, Gains of a Decade of Democracy, This Day Newspaper, May 29, p.25

Afegbua, I.A (2010). "Conflicts and Political Instability in Nigeria: Causes, Consequences and Prospects, Journal of Social Science and Public Policy 2-10-18

Adigun, A. (2003). "The Historical Antecedent of the Phenomenon of Ethnic Militias in Nigeria" in Babawale, T (ed) Urban Violence, Ethnic Militias and the Challenge of Democratic Consolidation in Nigeria. Lagos: Malthouse Press Ltd.

Alemika, E.E (2011). "Post-Election Violence in Nigeria: Emerging Trend and Lessons, CLEEN Foundation, July.

Cervellati, M \& Sunde,U. (2011). Democratization, Violent Social Conflicts and Growth, Discussion Paper of the School of Economics and Political Science, Department of Economics, University of ST Gallerio.

Egharevba, E.M \& Chiazor, A.I. (2012). Political Corruption and National Development in Nigeria, Paper Presented at the International Conference on Democracy, Governance and Curbing Corruption in 
Sub-Saharan Africa, Cheyney University of Pennsylvania, USA 810 August 2012.

Elaigwu, I. J. (2005b). The Politics of Federalism in Nigeria, Jos: Aha Publishing House Ltd.

Elaigwu, J. J. (2005). "Crises and Conflicts Management in Nigeria Since 1980" in Yakubu, A.M., Adegboye, R.T, Uba, C.N, Dogo,, B (eds) Crises and Conflict Management in Nigeria Since 1980, Vol, 1, Kaduna: Nigeria Defence Academy.

Fukuyama, F. (1992). The End of History and the Last Man, New York: Penguin Books

Haliru, T (2012). Ethnicity and Political Violence in Nigeria: Challenges of Democratic Governance, Journal of Research in Peace, Gender and Development Vol.2 (4): 89-94.

Hoglund, K. (2006). "Electoral Violence in War-Ravaged Societies: The Case Of Sri Lanka", Workshop Paper on Power Sharing and Democratic Governance in Divided Societies, Center for the Study of Civil War, PRIO August 21-22.

Horowitz, D.L. (1985). Ethnic Groups in Conflict, California: University Press.

Howard, J. (2004). Political Development in Emerging Nations: Is there A Third World? Belmont: Wadsworth Thomas Learning Inc.

Human Rights Watch (2011). "Nigeria; Post Election Violence Killed 800" May 16.

Ibeanu, O. (2009). "Oil, Environment and Conflict in the Coastal Zone of West Africa" in Ibeanu, O. And Ibrahim, J (eds) Beyond Resource Violence Civil Society and the Challenges of PeaceBuilding in West Africa, Centre for Democracy and Development (CDD) in Collaboration with West African Civil Society Forum (WACSOF) and African Security Sector Network (ASSN). Pp: 1-55

Ikejiaku, B (2012). "Poverty-Conflict Nexus: The Contentious Issue Revisited" European Journal of Sustainable Development, 1(2): $127-150$ 
Jawondo, I. A. (2011). "Political Violence and Attainment of Democratic Culture in Nigeria" International Journal of History, 3(3): 147-159

Joshua, S. Oni, S. \& Abgude, G. (2012). "Leadership, Democracy and Development in Nigeria: A Study of Oyo State (2003-2011), International Journal of Research in Arts and Social Sciences, 4, 161-173.

Keane, J. (2010). Does Democracy Have a Violent Heart? Retieved from http://johnkeane.net/wpcontent/uploads/2011/01/jk_democracy_violence_heart_june2010.p df on $13 / 3 / 2013$

Moaz, Z. \& Russett, B. (1993). Normative and Structural Causes of Democratic Peace, 1946-1986, American Political Science Review 87 (3): 624-638

National Bureau of Statistics (2012). 2010 Poverty and Income Distribution Report.

Nwanegbo, C.J (2005). "Them Against Us: A Critical Appraisal of the Bourgeosis/State Sponsored Conflicts in Anambra" in Yakubu, A.M.; Adegboye, R.T.; Uba, C.N and Dogo, B (eds) Crises and Conflict Management in Nigeria Since 1980, Vol.2 Kaduna: Nigeria Defence Academy. Pp: 466-483

Nwanolue, B.O.G \& Iwuoha, V.C (2012). "The Nigerian State and Democratization of Violence: Issues and Prospects", Journal of Arts and Contemporary Society, 4, 25-39

Nwolise, O.B.C. (1997). "ECOMOG Peace-Keeping Operation in Liberia: Effect on Political Stability in the West African Sub-Region" African Review, Journal of National Defence College, April 1(1): $36-60$

Obasanjo.O (2002) cited political thugery and violence in Nigeria. The bane of women participation in politics. Retrieved from http://www.articlebase.com/politics-articles/political-thugery-andviolence-in-nigeria-thebaneon16/8/2012

Odulami, T. (2008). Of Patriots and Traitors, The News Magazine, P. 38 
Ogbonaya, U.M, Omoju, O.E \& Udefuna, N.E (2012) The Challenges of Democratic Governance in Nigeria's 4th Republic, Mediterranean Journal of Social Sciences, 13 (11): 685-693

Omoweh, D and Okanya, D (2005). "Community unrest and Threat to Nigeria's National Security" in Ogwu, U.J (ED) New Horizon for Nigeria in World Affairs, Lagos: NIIA. Pp: 293-311

Onapajo, H. (2012). "Politics for God: Religion. Politics and Conflict in Democratic Nigeria" The Journal of Pan African Studies, 4 (9): 4266

Osita, O.O. (2007). Conflict Management in Nigeria Issues and Challenges, London: Adonis and Abbey Publishers Ltd

Otite, O. (2001). "On Conflicts, Their Resolution, Transformation, and Management" in Otite, O. And Albert, I.O (eds) Community Conflicts in Nigeria: Management, Resolution and Transformation, Ibadan: Spectrum Books Ltd. Pp: 1-33

Paris, R. (2004). At War's End: Building Peace After Civil Conflict, Cambridge: Cambridge University Press

Pius, R.M. (1986). American Government and Politics, New York: McGrawHill Books.

Remmer, K.L (1998). Does Democracy Promote Interstate Cooperation? Lessons from the Mercosur Region, International Studies Quarterly 42 (1): $25-51$

Reynal-Querol, M (2004). “Does Democracy Prempt Civil War?” European Journal of Political Economy, 21:445-465

Rummel, R. J. (undated) The Democratic Peace: A New Idea, retrieved from http://www.powerkill/POLSYS.ART.HTM on 28/2/2013

Russet, B. (2007). The Democratic Peace: What It Is and What It Isn't. Statement as Special Guest for the $25^{\text {th }}$ Anniversary Celebration of the World Society Foundation, Zurich, http://pantheon.yale.edu/brusset\Democratic_Peace.pdf

Saheed, Z. S (2012). "Impact of Social Crises on Economic Development: Theoretical Evidence from Nigeria" American International Journal of Contemporary Research, 2(6): 176-184 
Salawu, B. (2010). "Ethno-Religious Conflicts in Nigeria: Casual Analysis and Proposals for New Management Strategies" European Journal of Social Sciences, 13(3): 345-353

Saliu, H.A \& Lipede, A. (2008). "Constraints of Democracy in Nigeria" in Saliu, H.A, Jimoh, I.H, Yusuf, N and Ojo, E.O (eds) Perspectives on Nation-Building and Development in Nigeria Political and Legal Issues, Lagos: Concept Publications Ltd, Pp.120-151

Save Nigerian Group (2012). http.www.savenigeriagroup.com retrieved on $27 / 3 / 13$

Sodaro, M. J. (2001). Comparative Politics A Global Introduction, New York: McGraw-Hill

Taleski, D. (2011). Competition between Ethnic Parties in a Post-Conflict Context: Albanian Parties in Macedonia and Serbian Parties in Croatia, Paper for $61^{\text {st }}$ political Association Annual Conference Transforming Politics: New Synergies 19-21 April Novotel, London West.

Yahaya, A.O. (2005). "Role of Asset Valuation Models in Conflict Management" in Yakubu, A.M, Dogo, B, AND Adegboye, R.T (eds) in Crisis and Conflict Management in Nigeria Since 1980, Vol. 2 Kaduna: Nigerian Defence Academy. Pp: 665-673 